\title{
PENGARUH INVESTASI AGRO INDUSTRI DAN TINGKAT SUKU BUNGA SERTA TENAGA KERJA TERHADAP PRODUK DOMESTIK REGIONAL BRUTO DAN PENDAPATAN ASLI DAERAH KOTA SAMARINDA
}

\author{
Siti Maria \\ Fakultas Ekonomi Universitas Mulawarman Samarinda \\ E-mail:perpusmsi.unmul@gmail.com
}

\begin{abstract}
The purpose of this study are to determine the effect of agro industry Investment, interest rate, and labor toward gross regional domestic product (GRDP) and regional revenues in Samarinda city; and to describe the effect of gross regional domestic product (GRDP) toward the regional revenues in Samarinda City. The data analyzing used in this study is regressions in two ways. Based on the result, the researcher found that: first, the variable of agro industry investment, interest rate, and the amount of labor had significant effect toward regional domestic product (GRDP) in Samarinda city; Second, the variable of agro industry investment, interest rate, the amount of labor, and regional domestic product (GRDP) had significant effect toward regional revenues in Samarinda City; and third, gross regional domestic product (GRDP) was proved significantly affecting regional revenues in Samarinda city.
\end{abstract}

Keywords: Agro Industry Investment, Interest Rate, Labor, gross regional domestic product $(G R D P)$, regional income

\begin{abstract}
Abstrak
Tujuan dari penelitian ini adalah untuk mengetahui pengaruh investasi agro-sektor, nilai suku bunga kredit, dan tenaga kerja, Produk Domestik Regional Bruto (PDRB) dan Lokal Sendiri Pendapatan (PAD) di Kota Samarinda, serta untuk mengetahui pengaruh dari Produk Domestik Regional Bruto (PDRB) terhadap Pendapatan Asli Daerah $(P A D)$ di kota Samarinda. Alat analisis dalam penelitian ini menggunkan regresi dengan dua model. Berdasarkan hasil analisis dapat diketahui: Pertama, bahwa bahwa investasi sektor variabel agroindustri, nilai suku bunga kredit dan jumlah tenaga kerja memiliki pengaruh yang signifikan terhadap PDRB di Samarinda. Kedua, variabel investasi sektor agro-industri, suku bunga kredit, jumlah tenaga kerja dan PDRB memiliki pengaruh yang signifikan terhadap PAD di Samarinda. Ketiga, PDRB terbukti signifikan mempengaruhi PAD.
\end{abstract}

Kata Kunci: Investasi Agro Industri, Tingkat Suku Bunga, Tenaga Kerja, PDRB, PAD

Saat ini pengembangan agribisnis memerlukan langkah nyata untuk merangsang investasi, meningkatkan nilai tambah dan mencari pasar-pasar baru di luar negeri. Keseriusan upaya merangsang pertumbuhan tinggidi sektor pertanian adalah suatu keharusan apabila ingin mengembangkan sistemagroindustriberkerakyatan lebih modern dan lebih responsif 
terhadap perubahan global. Pengembangan agroindustri merupakan salah satu opsi yang perlu dipertimbangkan. Sebagai industriberbasis sumber daya, agroindustri berpotensi dapat meningkatkan cadangan devisa serta penyediaan lapangan kerja. Hal ini dinilai strategis mengingat Indonesiamerupakan satu dari sedikit negara di daerah tropis yang memiliki keragaman hayati (biodiversity) cukup besar. Untuk sektor perkebunan saja tidak kurang dari 145 komoditi yang tercatat sebagai komoditi binaan, sementara yang memiliki nilai ekonomis dapat diandalkan baru sekitar 10\% di antaranya kelapa sawit, karet, kopi, jambu mete (Saragih, 2003).

Agroindustri berasal dari dua kata agricultural dan industryyang berarti suatu industri yang menggunakan hasil pertanian sebagai bahan baku utamanya atau suatu industri yang menghasilkan suatu produk yang digunakan sebagai sarana atau input dalam usaha pertanian. Definisi agroindustri dapat dijabarkan sebagai kegiatan industri yang memanfaatkan hasil pertanian sebagai bahan baku, merancang, dan menyediakan peralatan serta jasa untuk kegiatan tersebut.

Menurut lrawandan Suparmoko (2006), bahwa pada umumnya di negara-negara sedang berkembang investasi pada sektor industri adalah yang terpenting demi untuk memaksimumkan kenaikan output. Perusahaan-perusahaan mengadakan investasi agar memperoleh keuntungan karena barang-barang modal berumur lebihdarisatu tahun maka keputusan investasi tergantung: (a) Tingkat permintaan atas output yang dihasilkan investasi baru. (b) Tingkat suku bunga dan pajak yang mempengaruhi. (c) Eksploitasi dan perkiraan kalangan usahawan atau situasi ekonomi di masa mendatang.

Samarinda memilikipotensi pertanian sangat besar, karenaitu harus mampu memberi nilai tambah dari hasil pertanian tersebut. Hal itu akan bisa dicapai hanya dengan pengembangan agroindustri. Program pertanian dalam arti luas dan konsep agroindustriitu dirancang untuk mengantisipasiberakhirnya kejayaan sumber daya alam.

Berdasarkan latar belakang tersebut di atas, maka penulis ingin mengkaji lebih jauh tentang pengaruh investasi sektor agro industri, tenaga kerja dan suku bunga terhadap Produk Domestik Regional Bruto (PDRB) dan Pendapatan Asli Daerah (PAD) Kota Samarinda diharapkan akan mampu menjawab tantangan saat ini dan masa yang akan datang. Adapun tujuan pada penelitian iniadalah: 1) Untuk mengetahui apakah variabel investasi agro industri, suku bunga, dan tenaga kerja berpengaruh langsung dan signifikan terhadap PDRB di Kota Samarinda; 2) Untuk mengetahui apakah variabel investasi sektor agroindustri, suku bunga, dan tenaga kerja berpengaruh langsung dan signifikan terhadap PAD di Kota Samarinda; 3) Untuk mengetahui apakah varabel PDRB berpengaruh langsung dan signifikan terhadap PAD di Kota Samarinda.

\section{Metode Penelitian}

Untuk memudahkan pemahaman terhadap istilah dan variabel yang digunakan dalam penelitian ini, maka perlu diberikan definisi operasional, adalah sebagai sebagai berikut: (1) investasi sektor agroindustri yaitu jumlah investasi Penanaman Modal Asing (PMA) dan Penanaman Modal Dalam Negeri(PMDN) sektor agroindustri di Kota Samarinda. (2) Nilai suku bunga kredit adalah nilai rata-rata tingkat suku bunga kredit bank untuk jangka waktu 1 tahun mengikuti suku bunga bank Indonesia. (3) Tenaga Kerja adalah jumlah orang yang bekerja di sektor agroindustri per tahun yang ada di Kota Samarinda. (4) Produk Domestik Regional Bruto 
(PDRB) adalah jumlah nilai barang dan jasa yang dihasilkan dari seluruh kegiatan perekonomian dari tahun tertentu atau periode tertentu di Kota Samarinda. (5) Pendapatan Asli Daerah (PAD) adalah pendapatan daerah yang bersumber dari hasil pajak daerah, hasil retribusi Daerah, hasil pengelolaan kekayaan daerah yang dipisahkan, dan lain-lain pendapatan asli daerah yang sah di Kota Samarinda.

Adapun data-data yang diperlukan untuk menganalisa dan membahas permasalahan yang dikemukakan terdahulu, adalah sebagai berikut: (1) Gambaran Umum Kota Samarinda. (2) Realisasi penerimaan investasi PMDN dan PMA sektor agro industri diKota Samarinda selama kurun waktu 20022011. (3) Suku Bunga Bank Indonesia selama kurun waktu 2002-2011. (4) jumlah orang yang bekerja di sektor agroindustri selama kurun waktu 2002-2011di Kota Samarinda. (5) Realisasi pendapatan asli daerah (PAD) yang bersumber dari hasil pajak daerah, hasil retribusi Daerah, hasil pengelolaan kekayaan daerah yang dipisahkan, dan lain-lain pendapatan asli daerah yang sah di Kota Samarinda tahun 2002-2011. (6) Produk Domestik RegionalBruto PDRB Atas Dasar Harga Konstan Menurut Lapangan Usaha di Kota Samarinda tahun 2002-2011.

Menurut Sugiono (2012:297). Analisis Jalur digunakan untuk mengetahui apakah data mendukung teori, yang secara apriori dihipotesiskan, yang mencakup kaitan struktural antar variabel terukur. Analisis Jalur atau yang lebih dikenal luas sebagai PathAnalysis merupakan suatu metode pendekomposisian korelasi kedalam bagian-bagian yang berbeda untuk menginterpretasikan suatu pengaruh (effect).

Langkah pertama analisis jalur adalah menerjemahkan hipotesis penelitian yang bentuknya proposisional ke dalam bentuk diagram yang disebut diagram jalur.

Pada saat menggambarkan diagram jalur ada beberapa perjanjian yaitu Hubungan antar variabel digambarkan oleh anak panah yang bisa berkepala tunggal $(\rightarrow)$ atau single headed arrow, dan berkepala dua $(\leftrightarrow)$ atau double headed arrow.

\section{Hasil Penelitian dan Pembahasan}

Hasil penelitian ini menemukan adanya pengaruh yang tidak signifikan antara variabel investasi agro industri terhadap PDRB. Karena investasi agro industri setiap tahunnya mengalami kenaikan fluktuatif dan untuk menguji signifikansi masing-masing variabel secara individu dilakukan Uji t-statistik. Variabel investasi tidak berpengaruh signifikan terhadap Produk Domestik Regional Bruto (PDRB), karena tingkat (sig > 0,05) yaitu $(0,709>0,05)$. Investasi sektor agroindustri $\left(\mathrm{X}_{1}\right)$ berpengaruh langsung terhadap PDRB $\left(\mathrm{Y}_{1}\right)$ sebesar 0,067.

Untuk mengukur signifikansi masingmasing variabel secara individu melalui Uji t-statistik. Variabel investasi sektor agroindustri berpengaruh signifikan terhadap PAD, karena tingkat $(\operatorname{sig}<0,05)$ yaitu $(0,021<$ $0,05)$. Investasi $\left(\mathrm{X}_{1}\right)$ berpengaruh langsung terhadap terhadap PAD ( $\left.\mathrm{Y}_{2}\right)$ sebesar 0,119 dan Investasi $\left(\mathrm{X}_{1}\right)$ berpengaruh tidak langsung terhadap terhadap PAD $\left(\mathrm{Y}_{2}\right)$ melalui $\operatorname{PDRB}\left(\mathrm{Y}_{1}\right)$ sebesar 0,067 x 0,911 =0,061. Penelitian ini sejalan dengan Bukhori(2010). Dalam penelitiannya investasi berpengaruh signifikan terhdap PAD.

Untuk menguji signifikansi dilakukan Uji t-statistik. Variabel nilai suku bunga kredit tidak berpengaruh signifikan terhadap PAD dengan nilai $(0,532>0,05)$, karena tingkat (sig > 0,05). Nilai suku bunga kredit $\left(\mathrm{X}_{2}\right)$ berpengaruh langsung terhadap $\mathrm{PAD}\left(\mathrm{Y}_{2}\right)$ 
sebesar-0,070, dan Nilai suku bunga kredit $\left(\mathrm{X}_{2}\right)$ berpengaruh tidak langsung terhadap terhadap PAD $\left(\mathrm{Y}_{2}\right)$ melalui PDRB $\left(\mathrm{Y}_{1}\right)$ sebesar $-0,021 \times 0,911=-0,019$. Penelitian ini sejalan dengan Kusyanto (2010), dalam penelitiannya suku bunga tidak berpengaruh signifikan karena kenaikan berfluktuatif.

Untuk menguji signifikansi dilakukan Uji t-statistik. Variabel jumlah tenaga kerja tidak berpengaruh signifikan terhadap PAD, karena tingkat $($ sig $>0,05)$ yaitu $(0,817>0,05)$. Jumlah tenaga kerja $\left(\mathrm{X}_{3}\right)$ berpengaruh langsung terhadap terhadap PAD $\left(\mathrm{Y}_{2}\right)$ sebesar 0,055 , dan Jumlah tenaga kerja $\left(\mathrm{X}_{3}\right)$ berpengaruh tidak langsung terhadap terhadap PAD $\left(\mathrm{Y}_{2}\right)$ melalui PDRB ( $\left.\mathrm{Y}_{1}\right)$ sebesar 1,009 $\mathrm{x} 0,911=0,120$. Penelitian ini sejalan dengan Bukhori (2010). Dalam penelitiannya tenaga kerja tidak berpengaruh signifikan terhadap PAD.

Untuk mengukur signifikansi melalui Uji t-statistik. Variabel PDRB memiliki pengaruh signifikan terhadap PAD sebesar $(0,006<0,05)$, karena tingkat (sig <0,05). PDRB $\left(\mathrm{Y}_{1}\right)$ berpengaruh langsung terhadap terhadap PAD $\left(\mathrm{Y}_{2}\right)$ sebesar 0,911. Penelitian ini sejalan dengan Bukhori (2010). Dalam penelitiannya PDRB berpengaruh signifikan terhdap PAD.

\section{Penutup}

Berdasarkan hasil analisis dan pembahasan maka dapat diambil beberapa simpulan sebagai berikut: (1) Investasi sektor agroindustriberpengaruh langsung dan tidak signifikan terhadap PDRB di Kota Samarinda. (2) Nilai suku bunga kredit berpengaruh langsung dan tidak signifikan terhadap PDRB di Kota Samarinda. (3) Tenaga kerja berpengaru langsung dan signifikan terhadap PDRB di Kota Samarinda. (4) Investasi sektor agroindustri berpengaruh langsung dan signifikan terhadap PAD di Kota Samarinda. (5) Nilai suku bunga kredit berpengaruh langsung dan tidak signifikan terhadap PAD di Kota Samarinda. (6) Tenaga kerja berpengaruh langsung dan tidak signifikan terhadap PAD di Kota Samarinda. (7) PDRB berpengaruh langsung dan signifika terhadap PAD di Kota Samarinda.

\section{DAFTAR PUSTAKA}

Anonim. (2007). Rencana Strategis Badan Agribisnis Repelita VII. Jakarta: Badan Agribisnis Departemen Pertanian Republik Indonesia. (2004). Undang-undang No.32 tahun 2004, Undang-undang Otonomi Daerah. Fokusmedia. Jakarta.

(2004) Undang-Undang No. 33 Tahun 2004 tentang Perimbangan Keuangan antaraPemerintah Pusat dan Pemerintah Daerah. Fokusmedia. Jakarta.

Austin, J.E. 2004. Agroindustrial Project Analysis. EDI Series in Economic Development. Washington, D.C.USA.

Baharsyah, S. 2006. Pendayagunaan Sumberdaya Manusia, IPTEK dan Faktor Penunjang lainnya dalam Pengembangan Agroindustri. Makalah pada Loka karya dan seminar. Pengembangan Agroindustri. Jakarta.

Budiono. 2002. Teori Pertumbuhan Ekonomi. BPFE UGM. Yogyakarta.

Elita. (2007. Penerimaan- Penerimaan Pendapatan Asli Daerah. Rajawali. Jakarta. 
Pengaruh Investasi Argo Industri dan Tingkat Suku Bunga... (Siti Maria)

Ghozali, Imam. 2005. Aplikasi Analisis Multivariate Dengan Program SPSS. Badan Penerbit Universitas Diponegoro. Semarang.

Hadi, Prayitno. 2002. Perekonomian Indonesia. Ghalia. Jakarta.

Hakim, Abdul. 2010. Ekonomi Pembangunan (Cetakan Ke Dua). Ekonisia. Yogyakarta.

Halim, Abdul. 2004. Manajemen Keuangan Daerah. UPP AMP. YKPN. Yogyakarta.

Hardinsyah dan Martianto. 2004. Pembangunan Ketahanan Pangan yang Berbasis Agribisnis dan Pemberdayaan Masyarakat. Makalah pada Seminar Nasional Ketahanan Pangan. Jakarta, 29 Maret 2004.

Irawan dan M. Suparmoko. 2006. Ekonomi Pembangunan. Liberti. Yogyakarta.

Irianto, Jusuf. 2005. Industri Kecil dalam Perspektif Pembinaan dan Pengembangan. Erlangga. Surabaya.

Kadariyah. 2003. Ekonomi Perencanaan Program Pembangunan Nasional BAPPENAS. Lembaga Penerbitan Fakultas Ekonomi Universitas Indonesia. Jakarta.

Kartasapoetra, G. 2004. Manajemen Pertanian (Agribisnis). PT. Bina Aksara. Jakarta.

Lukmana, A. 2007. Peluang dan Tantangan Agroindustri dalam Menghadapi Era Globalisasi. Makalah Seminar Sehari tentang Peluang dan Tantangan Agroindustri dalam Menghadapi Era Globalisasi. Fateta IPB. Bogor.
Pratiwi. 2005. Analisis Investasi dan Manajemen. Erlangga. Jakarta.

Riduan, Engkos A.K. 2007. Analisis Jalur (Path Analysis). Alfabeta. Bandung.

Rusmalia, Siti. 2007. Pengaruh Investasi Komulatif dan Tenaga Kerja Terhadap Nilai Tambah Pada Sektor Industri di Kalimantan Timur. Tesis Pasca Sarjana, Universitas Hasanudin.

Saragih, Bungaran. 2003. Kebijakan Pertanian untuk Merealisasikan Agribisnis sebagai Penggerak Utama Perekonomian Negara. Paper pada PanelDiskusi Jakarta American Club. Jakarta, November 14, 2003. Centre policy for agro studies.

Sastrowardoyo. 2006. Ekonomi Pembangunan Problematika dan Pendekatan. Salemba Empat. Jakarta. 
